\title{
OVARIAN TERATOMA IN ROUTINE BIOPSY MATERIAL DURING A FIVE-YEAR PERIOD
}

\author{
Marina Kos ${ }^{1,2}$, Jasmina Nikić ${ }^{1}$ and Tanja Leniček ${ }^{1}$ \\ ${ }^{1}$ Ljudevit Jurak Clinical Department of Pathology, Sestre milosrdnice University Hospital Center; \\ ${ }^{2}$ School of Medicine, University of Zagreb, Zagreb, Croatia
}

\begin{abstract}
SUMMARY - Teratomas are tumors derived from germ cells, most frequently arising in the gonads. The aim of this study was to determine the number of ovarian teratomas diagnosed in the routine biopsy material at Ljudevit Jurak Clinical Department of Pathology, Sestre milosrdnice University Hospital Center during a 5-year period, as well as their clinical, gross and microscopic characteristics. Teratomas accounted for $48.6 \%(\mathrm{n}=166)$ of primary ovarian tumors. The patient mean age was $34.74 \pm 12.37$ years. Difference in the incidence of teratoma between the left and right ovary was not significant; bilateral teratoma was found in 13 patients. Teratomas were detected by ultrasonography in $115(69.27 \%)$ cases and the rest were found during surgery performed for other indications. Most teratomas ( $\mathrm{n}=161 ; 96.9 \%)$ were mature and cystic (dermoid cysts). Mature and solid teratomas were diagnosed in 5 (3.01\%), ovarian struma in $2(1.8 \%)$ cases and strumal carcinoid in $1(1.2 \%)$ case. Mature cystic teratomas contained sebaceous material in $123(76.8 \%)$ cases, and a total of 16 teeth were found; 157 (94.5\%) teratomas measured $<10 \mathrm{~cm}$ in largest diameter. Microscopically, mature cystic teratomas most frequently contained ectodermal (skin with appendages, mature glia and nerve ganglia) and mesodermal (fibrous, fat tissue, cartilage and bone) tissues. Frequently found tissues of endodermal origin were respiratory and intestinal epithelia. Small foci of thyroid tissue were found in $20(12 \%)$ teratomas. Chronic granulomatous foreign body reaction in the wall of mature cystic teratomas was found in 11 (6.8\%) tumors.
\end{abstract}

Key words: Teratoma - diagnosis; Struma ovarii - diagnosis; Carcinoid tumor

\section{Introduction}

Teratomas are fascinating, most frequently benign tumors, derived from germ cells and commonly arising in the gonads. They can also develop along the body midline (base of the skull, mediastinum, sacrococcygeal region), which is a migratory pathway of the primordial germ cells from the yolk sac ${ }^{1,2}$. In the sacrococcygeal area, teratomas arise as congenital tumors; in the testicles teratomas usually develop in childhood, but ovarian teratomas can arise throughout the lifespan, being most frequent in the reproductive period ${ }^{1,3,4}$.

Correspondence to: Marina Kos, $M D, P b D$, Ljudevit Jurak Clinical Department of Pathology, Sestre milosrdnice University Hospital Center, Vinogradska c. 29, HR-10000 Zagreb, Croatia

E-mail: dr_marina_kos@yahoo.com

Received February 5, 2014, accepted November 3, 2015
The most common symptoms of ovarian teratomas are pressure, pelvic pain and irregular bleeding, but the symptoms can also result from complications such as torsion, rupture, peritonitis and autoimmune hemolytic anemia ${ }^{2-4}$. Most ovarian teratomas are grossly cystic, but they can also be solid. Microscopically, they can be composed of tissues derived from all three embryonic layers, i.e. ectoderm, mesoderm and endoderm. The tissues in teratomas are usually well differentiated (i.e. mature), but they can also remain at the fetal stage of development (i.e. immature). The most common immature tissue found in teratomas is neuroectodermal tissue, and such tumors are considered malignant. Mature teratoma can undergo malignant transformation in $2 \%$ of cases (the malignant component being most frequently squamous cell carcinoma). The treatment of teratomas is surgical (salpingo-oophorectomy 
or resection of the ovary), and depends upon the age of the patient and the volume of the tumor. Immature teratomas are treated by a combination of surgery and multimodal chemotherapy ${ }^{3,5,6}$. The aim of this study was to determine the number of ovarian teratomas in the routine biopsy material received and diagnosed at Ljudevit Jurak Clinical Department of Pathology, Sestre milosrdnice University Hospital Center during a 5-year period, as well as their clinical, gross and microscopic characteristics.

\section{Materials and Methods}

Using the Thanatos computer program designed for routine pathologic sample description and documentation, data on the number of biopsy samples of the ovary received during the period from October 1, 2005 until September 30,2010 were retrieved. Because the study period was relatively short, it was divided into one-year intervals, as follows: interval 1 starting on October 1, 2005 and ending on September 30, 2006; interval 2 starting on October 1, 2006 and ending on September 30, 2007; interval 3 starting on October 1, 2007 and ending on September 30, 2008; interval 4 starting on October 1, 2008 and ending on September 30, 2009; and interval 5 starting on October 1, 2009 and ending on September 30, 2010. The Thanatos program was searched for the following keywords: dermoid cystic, solid and immature teratoma (lat. teratoma dermoides cysticum, teratoma solidum and teratoma immaturum), struma of the ovary (lat. struma ovarii) and carcinoid of the ovary (lat. carcinoides ovarii). Diagnoses were made on the routine biopsy material of the ovary removed by laparoscopy or laparotomy, after routine fixation and paraffin embedding. The tissue was routinely cut at $5 \mu \mathrm{m}$, stained with hematoxylin-eosin (H-E) and examined by light microscopy. When necessary, immunohistochemical analysis was done, using appropriate antibodies, most frequently against thyroglobulin, calcitonin, synaptophysin, chromogranin A, vimentin and desmin, according to the manufacturer's manual (Dako, Denmark). After the diagnoses that contained the keywords for the analyzed period were found, the age of patients, the way the tumor was clinically discovered, the laterality and size of the tumor, and the gross and microscopic features of the tumors were analyzed. Regarding the size, teratomas were divided into 4 groups: group 1 with greatest diameter $<5 \mathrm{~cm}$, group 2 with greatest diameter 5.1-10 cm, group 3 with greatest diameter 10.1$15 \mathrm{~cm}$, and group 4 with greatest diameter $>15 \mathrm{~cm}$.

\section{Results}

During the 5-year period analyzed, 1580 biopsy specimens of the ovary were received for histopathologic examination. In 370 (23.4\%) cases, primary ovarian tumor was diagnosed. Teratomas were diagnosed in 153 patients, but in 13 cases the tumors were bilateral, so the total number of diagnosed teratomas was $166 / 370$ cases (44.86\%). Distribution according to one-year intervals showed that 46/166 (27.7\%) teratomas were found in interval 3; 35/166 (21.1\%) teratomas in interval $1 ; 29 / 166$ (17.5\%) teratomas in intervals 2 and 4 each; and the lowest number of cases, 27/166 (16.3\%) in interval 5 (Fig. 1).

Difference in the incidence of teratomas diagnosed in one-year intervals was not significant. In 56/153 $(36.6 \%)$ patients, teratoma arose in the left ovary and in $67 / 153(43.8 \%)$ patients in the right ovary $\left(\chi^{2}=1.359\right.$, $\mathrm{p}<0.05$, NS). Bilateral teratomas were found in $13 / 153$ (8.5\%) patients. In 17/153 (11.1\%) patients, the laterality of the ovary was not noted in pathologic report, presumably because the tumor was discovered incidentally, in the specimen from hystero-salpingo-oophorectomy, and the uterus was so deformed that it was not possible to determine which ovary was the left and the right one. In one case, the patient underwent surgery for teratoma of the left ovary in 2007 and for teratoma of the right ovary in 2008 (at the time of the first operation she was aged 40). One patient had first surgery for ovarian teratoma before 2005 and the diagnosis of that tumor was not included in the analysis. In

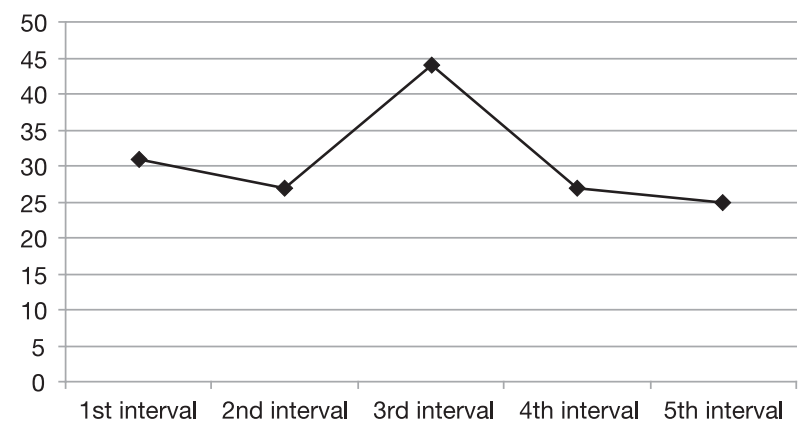

Fig. 1. Number of ovarian teratoma cases diagnosed in 1-year intervals during the 5-year study period (NS). 
Fig. 2. Age distribution of patients with ovarian teratoma.

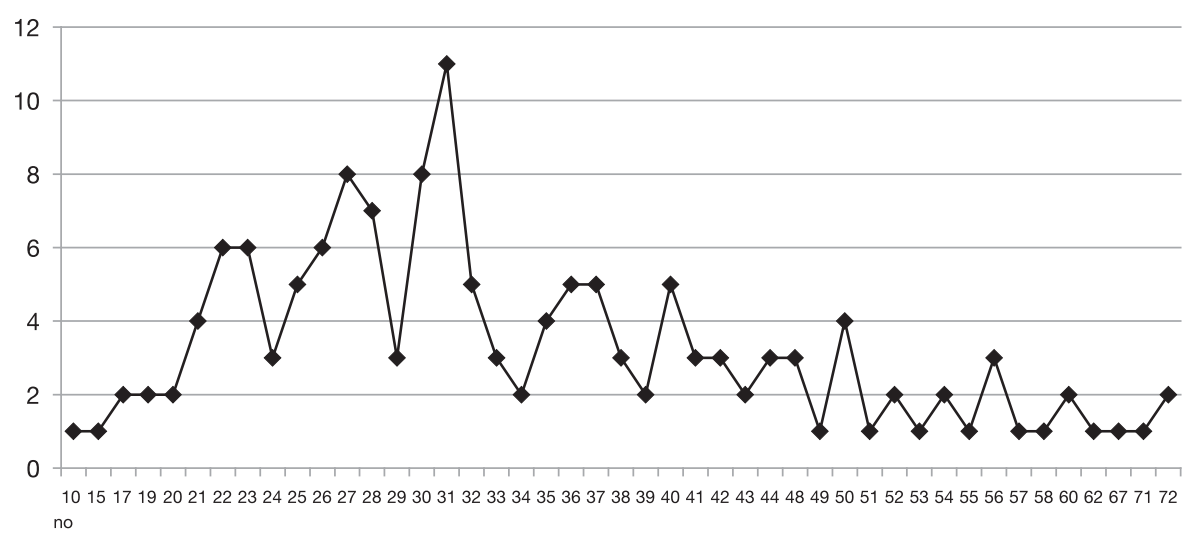

Mature solid teratomas were diagnosed in 5/166 (3.01\%) cases, 3 of them (1.8\%) being ovarian struma (Fig. 3), while in 2 cases (1.2\%) strumal carcinoid was diagnosed. On gross examination, 16 well formed teeth were discovered protruding into the cystic cavity of the tumor, 4 of them from Rokitansky's protuberance. In most teeth containing tumors, only one tooth was found, while 2 teeth were found in 2 cases.

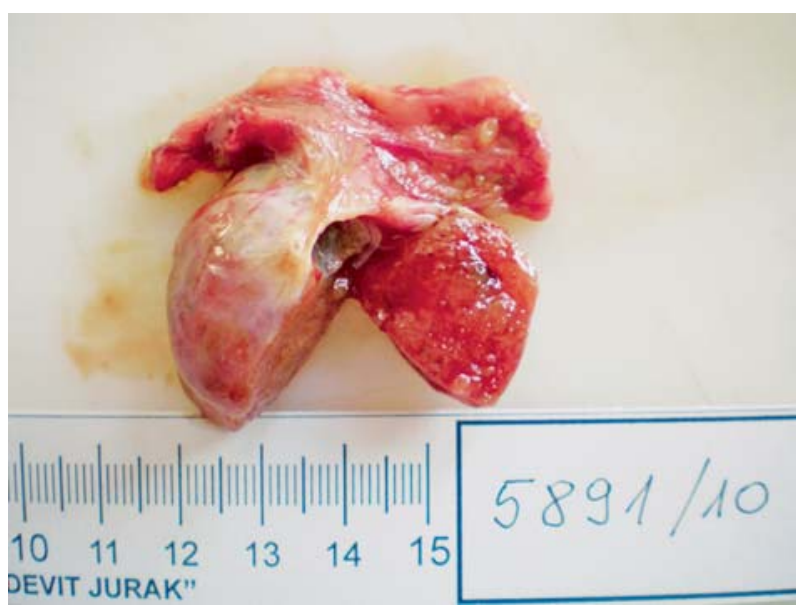

Fig. 3. Solid teratoma grossly resembling thyroid tissue. Histopathologic diagnosis was ovarian struma.

Histogenetically, teratomas most commonly contained tissues of ectodermal origin. Skin with appendages was found in 155/161 (96.3\%) cases, followed by mature glia in 50/161 (3.1\%), well formed ganglion(s) in $27 / 161$ (16.3\%) and choroid plexus in 6/161 (3.3\%) cases (Fig. 4).

Among mesodermally derived tissues, connective tissue was found in 149/161 (92.5\%), adipose tissue in $130 / 161$ (80.7\%), hyaline cartilage in 56/161 (34.7\%), 


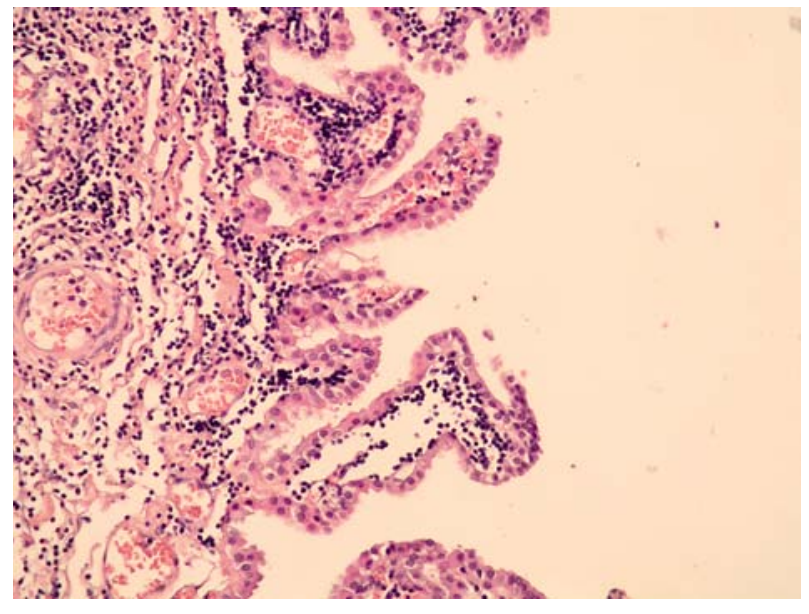

Fig. 4. Choroid plexus in one of the cystic spaces in the wall of cystic teratoma. It was surrounded by mature glial tissue (HE, X200).

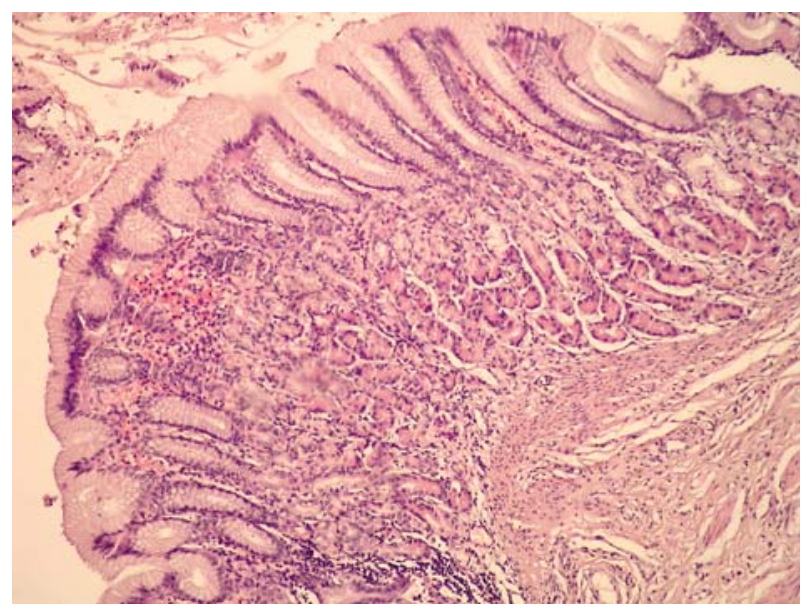

Fig. 5. Well differentiated gastric mucosa covering a part of the cystic cavity in a mature cystic teratoma (HE, X100).

bone in $41 / 161$ (25.4\%), smooth muscle in 20/161 (12.4\%) and skeletal muscle in 6/161 (3.7\%) teratomas. Ectodermal derivatives were the rarest finding, the most frequent of them being respiratory epithelium in 52/161 (32.3\%), different types of gastrointestinal tract epithelia ranging from gastric to colonic epithelium in 13/161 (8.1\%) (Fig. 5), ependyma in 8/161 (4.9\%) and transitional epithelium in 6/161 (3.7\%) teratomas.

According to histogenesis, the tissues found in teratomas are summarized in Table 1. The most frequently found glandular tissue in mature cystic teratomas was thyroid tissue in 20/161 (12.4\%), small mucous glands in 15/161 (9.3\%), and salivary gland tissue in 10/161 (6.2\%) cases. Adrenal and breast tissue was found in $1 / 161(0.6 \%)$ case each. In 1/161 (0.6\%) case, the tissue of pigmented nevus was also found. In $11 / 161(6.8 \%)$ cases of cystic teratoma, the wall contained a conspicuous chronic foreign body inflammatory reaction with numerous lipid laden macrophages, probably due to destruction of the lining epithelium and leakage of sebaceous cyst contents into the wall. In 7/161 (4.3\%) cases, abundant clusters of lymphocytes without germinal centers were found. The diagnosis of ovarian struma was made in 3/166 (1.8\%) and the diagnosis of strumal carcinoid in 2/166 (1.2\%) teratomas. In all 3 cases of ovarian struma, thyroid tissue was well differentiated, whereas in strumal carcinoid, carcinoid tumor confirmed by immunohistochemical methods was found besides thyroid tissue.

Table 1. Tissues found in cystic ovarian teratomas $(N=161)$ according to their histogenesis

\begin{tabular}{|l|c|c|}
\hline Origin/type of tissue & $\mathrm{n}$ & $\%$ \\
\hline Ectoderm & & \\
Skin with appendages & 155 & 96.3 \\
Glia & 50 & 31 \\
Ganglions & 27 & 16.8 \\
Choroid plexus & 6 & 3.7 \\
\hline Mesoderm & & \\
Connective tissue & 149 & 92.5 \\
Adipose tissue & 130 & 80.7 \\
Hyaline cartilage & 56 & 34.8 \\
Bone tissue & 41 & 25.4 \\
Smooth muscle & 20 & 12.4 \\
Skeletal muscle & 6 & 3.7 \\
\hline Endoderm & & \\
Respiratory epithelium & 52 & 32.3 \\
Intestinal epithelium & 13 & 8.1 \\
Ependyma & 8 & 4.9 \\
Transitional epithelium & 6 & 3.7 \\
\hline
\end{tabular}

\section{Discussion}

According to the literature, mature cystic ovarian teratomas are the most common ovarian germ cell tumors, accounting for around $20 \%$ of all ovarian tu- 
mors ${ }^{9}$. In our research, teratomas comprised 166 (44.9\%) of all ovarian tumors during the 5-year study period. The reason for this discrepancy is hard to explain. One of the reasons could be that literature data on the incidence of ovarian teratoma are relatively outdated and that the incidence of these tumors has, in the past sixty years, increased under the influence of various environmental factors generally connected with increased tumor incidence. The difference (although not statistically significant) in the number of teratomas diagnosed in particular years during the 5 -year study period is unexplainable. As nowadays ovarian tumors are most commonly discovered ultrasonically, these differences might possibly be explained by individual history and clinical data. In our study, teratomas were diagnosed ultrasonically in $69.3 \%$ of patients, but in $9.2 \%$ of cases teratoma was detected incidentally during surgical procedure for another indication. The information on the way in which the remaining $22.3 \%$ of teratomas were discovered could not be confirmed with certainty. Data on patient age were consistent with literature data, since most of the patients in this study were in the reproductive age, although the age range was from 10 to 72 years $^{10}$. Although teratomas were found more frequently in the right than in the left ovary, the difference was not significant. In $8.5 \%$ of cases, teratomas were bilateral, which confirmed the results of other studies9. Although teratomas can reach huge proportions, in this study the largest diameter was up to $5 \mathrm{~cm}$ in 106 (63.9\%) and up to $10 \mathrm{~cm}$ in 157 (94.6\%) cases, confirming again the results of other studies ${ }^{9,11}$. Grossly, most teratomas in this study were mature cystic (dermoid cysts), containing sebaceous, necrotic and mucinous material in $96.9 \%$, while in $4.7 \%$ the content was not precisely described. In comparison to $31 \%$ of cases in which well formed teeth were grossly found, in this study, only $9.5 \%$ of mature cystic teratomas contained teeth $^{12}$. On microscopic examination, all mature cystic teratomas contained tissues of ectodermal origin, mostly skin with appendages and mature glia. Of tissues of mesodermal origin, connective and mature adipose tissues were most commonly found, followed by hyaline cartilage and well formed bone fragments. Of tissues of endodermal origin, respiratory epithelium and epithelium of different levels of the digestive tract were most frequent. Thyroid tissue was found in smaller foci in $12.5 \%$ of mature cystic and/or solid terato- mas, but because of its focality, the findings did not warrant the diagnosis of struma ovarii. Struma ovarii was diagnosed in $1.8 \%$ of all teratomas. Struma ovarii was, in this study, the only example of monodermal teratomas that are very rare and by definition have to contain only one type of tissue from one of the embryonic layers (mostly ectoderm or endoderm $)^{4,7}$. All the pathologic processes found in the thyroid gland of normal localization can also develop in an ovarian struma ${ }^{7}$. Carcinoid of the ovary is diagnosed on conventional, $\mathrm{H}-\mathrm{E}$ stained slides, and the diagnosis is confirmed immunohistocemically using neuroendocrine markers such as chromogranin A, synaptophysin and neuron specific enolase in the cytoplasm of tumor cells ${ }^{8}$. In both cases of strumal carcinoid in this study, besides thyroid tissue, tumorous tissue showed a mixture of insular and trabecular growth of cells with at the most 2 and 4 mitoses $/ 10$ high power fields. Immunohistochemically, thyroid tissue showed positive reaction with thyroglobulin and thyroid transcription factor, while in carcinoid tissue the expression of these markers was negative. Conversely, the carcinoid tissue cells immunohistochemically showed expression of chromogranin A and synaptophysin. Patients with primary carcinoid of the ovary are most often perimenopausal or postmenopausal, and in this study one of the patients was 40 and the other 44 years of age. In both cases, the tumor was removed because of the diagnosis made by ultrasound. Although carcinoid syndrome can be present in $30 \%$ of patients with insular, $13 \%$ with trabecular and $3.2 \%$ with strumal carcinoid of the ovary, typically withdrawing after surgical removal of the tumor, the information whether the carcinoid patients in this study had some symptoms was not available. However, because of the rarity of carcinoid syndrome associated with strumal carcinoid of the ovary, it is supposed that it was not the case $\mathrm{c}^{12-14}$.

\section{References}

1. Faure-Conter C, Rocourt N, Sudour-Bonnage H, et al. Pediatric germ cell tumors. Bull Cancer. 2013;100:381-91.

2. Linder D, McCaw BK, Hecht F. Parthenogenetic origin of benign ovarian teratoma. N Engl J Med. 1975;292:63-6.

3. Medeiros F, Crum CP. Germ cell tumors of the ovary. In Crum CP, Nucci M, Lee KR, editors. Diagnostic gynecologic and obstetric pathology, $2^{\text {nd }}$ ed. Philadelphia: Elsevier Saunders, 2011; 905-37. 
4. Tallerman A, Vang R. Germ cell tumors of the ovary. In: Kurman RJ, Ellenson Hedrick L, Ronnett, editors. Blaustein's Pathology of the Female Genital Tract, $6^{\text {th }}$ ed. New York: Springer, 2011;847-907.

5. Bonazzi C, Peccatori F, Colombo N, Lucchini V, Canto MG, Mangioni C. Pure ovarian immature teratoma, a unique and curable disease: 10 years' experience of 32 prospectively treated patients. Obstet Gynecol. 1994;84:598-604.

6. Mitui AH, Fujita R, Sugata F, Kienenbuchi M, Suzuki K, Sagawa F. A case of ovarian dermoid cyst with malignant transformation perforated into the rectosigmoid colon and small intestine. Endoscopy. 1983;15:331-3.

7. Prasad P, Nunns D, Ubhi CS, Chaudry Z, Soomro I. A rare case of follicular thyroid carcinoma in ovarian struma. Surgeon. 2008;6:313-5.

8. Leniček T, Tomas D, Soljačić-Vraneš H, Kraljević Z, Klarić P, Kos M, Kos M. Strumal carcinoid of the ovary: report of two cases. Acta Clin Croat. 2012;51:649-53.
9. Petersen WF, Prevost EC, Edmunds FT, Hundley JM Jr, Morris FK. Benign cystic teratomas of the ovary; a clinico-statistical study of 1007 cases with a review of the literature. Am J Obstet Gynecol. 1955;70:368-82.

10. Crouet H, de Ranieri E, de Ranieri J. Secondary cancers arising in mature benign cystic teratomas of the ovary (dermoid cysts). Review of the literature apropos of a new case. J Gynecol Obstet Biol Reprod (Paris). 1986;15:1055-66.

11. Comerci JT Jr, Licciardi F, Bergh PA, Gregori C, Breen JL. Mature cystic teratoma: a clinicopathologic evaluation of 517 cases and review of the literature. Obstet Gynecol. 1994;84:22-8.

12. Robboy SJ, Norris HJ, Scully RE. Insular carcinoid primary in the ovary: a clinicopathologic analysis of 48 cases. Cancer. 1975;36:404-18.

13. Davis KP, Hartmann LK, Keeney GL, Shapiro H. Primary ovarian carcinoid tumors. Gynecol Oncol. 1996;61:259-65.

14. Soga J, Osaka M, Yakuwa Y. Carcinoids of the ovary: an analysis of 329 reported cases. J Exp Clin Cancer Res. 2000;19:271-80.

Sažetak

\section{TERATOM JAJNIKA U RUTINSKOM BIOPTIČKOM MATERIJALU U PETOGODIŠNJEM RAZDOBLJU}

\section{Kos, J. Nikić i T. Leniček}

Teratomi su tumori podrijetla zametnih stanica koji se najčešće razvijaju u gonadama. Cilj rada bio je utvrditi koliko je dijagnoza teratoma jajnika postavljeno na rutinskom bioptičkom materijalu Kliničkoga zavoda za patologiju „Ljudevit Jurak“ Kliničkoga bolničkog centra „Sestre milosrdnice“ u Zagrebu u petogodišnjem razdoblju, kao i koje su bile njihove kliničke, makroskopske i mikroskopske osobine. U analiziranom razdoblju teratomi su sačinjavali 166 (44,86\%) primarnih tumora jajnika. Srednja dob bolesnica s teratomom jajnika bila je 35 $\pm 12,37$ godina. Nije pronađena statistički značajna razlika u učestalosti teratoma lijevog i desnog jajnika, a u 13 (7,8\%) bolesnica teratom je bio obostran. Teratom je u $115(69.3 \%)$ slučajeva otkriven ultrazvukom, u $21(12,6 \%)$ je ultrazvukom postavljena dijagnoza nespecificiranog cističnog tumora, a u 16 $(9,6 \%)$ slučajeva teratom je otkriven prilikom operacijskog zahvata učinjenog iz nekog drugog razloga. U $160(96,4 \%)$ slučajeva radilo se o zrelim cističnim teratomima (dermoidnim cistama), od kojih je $123(76,8 \%)$ bilo ispunjeno lojem i u kojima je pronađeno sveukupno 16 zuba. U 157 (94,6\%) slučajeva najveći promjer teratoma iznosio je do $10 \mathrm{~cm}$. Mikroskopski, zreli cistični teratomi najčešće su sadržavali tkiva ektodermalnog i mezodermalnog podrijetla i to u $154(96,3 \%)$ slučaja kožu s kožnim adneksima, odnosno u 148 (92,54\%) slučaja vezivo. Od drugih ektodermalnih tkiva po učestalosti su slijedili zrela glija i živčani gangliji, a od mezodermalnih tkiva zrelo masno tkivo, hrskavica i kost. Od tkiva endodermalnog podrijetla najčešće je pronađen respiracijski i crijevni epitel. Manja žarišta tkiva štitnjače pronađena su u 19 (12\%) cističnih teratoma. U $11(7 \%)$ cističnih teratoma u stijenci su pronađena žarišta kronične upale tipa stranog tijela. Solidne građe bilo je $5(3 \%)$ teratoma, od čega u 3 (2\%) slučaja struma jajnika, a u 2 (1\%) slučaja strumalni karcinoid.

Ključne riječi: Teratom - dijagnostika; Struma jajnika - dijagnostika; Karcinoidni tumor 